\title{
12th IFDC 2017 special issue - Iodine, selenium and iron contents in Portuguese key foods as consumed ${ }^{\text {is }}$
}

\author{
Inês Delgado ${ }^{\mathrm{a}, \mathrm{b}}$, Marta Ventura ${ }^{\mathrm{a}, \mathrm{c}}$, Sandra Gueifão ${ }^{\mathrm{a}}$, Inês Coelho ${ }^{\mathrm{a}, \mathrm{b}}$, Ana Cláudia Nascimento ${ }^{\mathrm{a}}$, \\ José Armando L. Silva ${ }^{\mathrm{d}}$, Isabel Castanheira ${ }^{\mathrm{a}, *}$ \\ ${ }^{a}$ Departamento de Alimentação e Nutrição, Instituto Nacional de Saúde Doutor Ricardo Jorge, INSA. IP, Avenida Padre Cruz, 1649-016, Lisboa, Portugal \\ ${ }^{\mathrm{b}}$ Departamento de Engenharia Química, Instituto Superior Técnico, Av. Rovisco Pais, 1049-001, Lisboa, Portugal \\ ${ }^{\mathrm{c}}$ Departamento de Ciências e Engenharia do Ambiente, Faculdade de Ciências e Tecnologia da Universidade Nova de Lisboa, 2829-516, Caparica, Portugal \\ ${ }^{\mathrm{d}}$ Centro de Química Estrutural, Instituto Superior Técnico, Universidade de Lisboa, Av. Rovisco Pais, 1, 1049-001, Lisboa, Portugal
}

\section{A R T I C L E I N F O}

\section{Keywords:}

Iodine

Selenium

Iron

Total Diet Study

Seasonality

Recommended nutrient intake

Food analysis

Food composition

\begin{abstract}
A B S T R A C T
Iodine, selenium and iron are micronutrients essential for thyroid hormone synthesis causing their low plasma levels an additional risk of autoimmune thyroid diseases. A Portuguese TDS pilot study representative of diets in Portugal was carried out, since foods are the main natural sources of these micronutrients. Six hundred and twenty-four samples were collected based on local markets and later analysed in pools of ten meat samples, twenty-seven fish, nine chicken eggs and six cow dairy products. The iodine and selenium contents were determined using ICP-MS after alkaline (iodine) or acid digestion (selenium) and iron by ICP-OES after acid digestion. The highest content of three oligoelements was detected in fish. Meat had lower iodine content and the dairy products lower selenium and iron levels. Sardine presented significant different levels in summer and winter for iodine, and in summer and autumn for selenium, mackerel had diverse contents of iron in summer and autumn. The contribution of salmon and milk for iodine RNI was around $40 \%$, for children and adults. Shrimp is also the food with more selenium, exceeding 1.5 times the \% RNI for children and adults females, while iron maximum contribution was observed in meat for children and adult males.
\end{abstract}

\section{Introduction}

Some trace elements are essential for the performance of thyroid hormones, namely iodine, selenium and iron (Zimmermann and Köhrle, 2002).

Iodine is a substrate of thyroperoxidases (TPO) to synthetize hormones thyroxine (T4) and triiodothyroxine (T3) as well as monoiodotyrosine (MIT) and diiodotyrosine (DIT) (Rohner et al., 2014; Zimmermann, 2012). T4 and T3 are very important for the proper functioning of the thyroid, regulating cellular metabolism and an active participation in the growth and development of organs, especially the brain (Boyages, 1993). A poor thyroid performance can lead to hypothyroidism and brain damage, resulting in mental retardation. Other impairments associated with malfunction of thyroid are the goiter and hyperthyroidism multinodular (Rohner et al., 2014).

Thyroid is the organ with the highest concentration of selenoproteins (Hu and Rayman, 2017; Köhrle, 2013). Selenium deficiency can lead to an accumulation of peroxidases and damage the thyroid (Arthur et al., 1999; Rohner et al., 2014; Zimmermann and Köhrle, 2002) and Hashimoto's Thyroidits (Hu and Rayman, 2017; Yao et al., 2011).

Thyroperoxidases are iron-dependent (Rohner et al., 2014). The deficiency of this element leads to a reduction of the TPO activity, increasing disease risk (Hess et al., 2002; Zimmermann et al., 2000).

Deficiencies of iodine, selenium and iron, can be avoided by eating foods containing them in an available form.

One of the best ways to scrutinise nutrient contents in foods is through the Food Composition Databases (FCDB). Usually, FCDB are well-documented with more than 1000 foods and providing values from almost 40 nutrients representing consumed foods of a country. Their updates are critical to calculate real nutrient intake, to monitor nutrient status of population (Egan et al., 2007; Ottley, 2005), to study health/ disease/relationship or to develop nutrient policies, since the level of certain nutrients has small variations among countries. In this study was performed a comparison of FCDB and for that, the same or similar food item was chosen. All values were categorised according to data types: original analytical values, imputed values, calculated values,

\footnotetext{
This paper was a Poster at the 12th IFDC, 11-13 October 2017, Buenos Aires, Argentina.

* Corresponding author.

E-mail address: isabel.castanheira@insa.min-saude.pt (I. Castanheira).
} 
borrowed values or presumed values (Greenfield and Southgate, 1992).

The main goal of this work is the evaluation of I, Se and Fe contents in key foods collected during the Portuguese Total Diet Study and thus, as secondary goal, to determine the percentage of the recommended nutrient intake for each trace element.

\section{Materials and methods}

\subsection{Sampling plan}

The sampling plan of this work is representative of the Portuguese diet, as delineated in the Total Diet Study Exposure project (Dofkova et al., 2016; Elegbede et al., 2017). A 24-h dietary recall on two nonconsecutive days to collect data of food consumption was applied, covering 3529 individuals of both sexes with 18-93 years from all regions of the country (continental Portugal and islands). In accordance with the food classification system adopted by EFSA (FoodEx 2), foods were categorised into four groups of protein-rich of animal origin: fish and seafood, cow milk and milk products, chicken eggs and meat, covering the most significant food items (European Food Safety Authority (EFSA), 2015). The shopping list was created based on food consumption data to collect the most consumed brands from all the regions. Samples were purchased from Portuguese supermarkets, raw or as consumed, during 2015 and 2016. The 624 foods collected were analysed, as consumed, in 52 pooled samples, each consisting of 12 identical foods. The characterization of pools is presented in Supplementary Table 1 .

\subsection{Chemicals}

All reagents were of high analytical grade. The ultra-pure water level I for all purposes was obtained with a Milli-Q Element system from Millipore (Millipore Corporation, Saint-Quentin, France).

\subsubsection{Iodine determination}

Working standard solutions of iodine were prepared from singleelement high purity ICP stock standard containing $1000 \mathrm{mg} / \mathrm{L}$ of iodine (Inorganic Ventures, Christiansburg, Virginia). Internal standard solutions of rhodium $(10 \mathrm{mg} / \mathrm{L})$ and tellurium solution $(1000 \mathrm{mg} / \mathrm{L})$ were purchased from Inorganic Ventures (Christiansburg, Virginia) and Merck (Darmstadt, Germany), respectively. Tetramethylammonium hydroxide (TMAH) $(25 \% \mathrm{v} / \mathrm{v})$ was from Fluka, Honeywell (Bucharest, Romania). Working standard solutions and blanks were prepared in a $0.5 \%(\mathrm{v} / \mathrm{v})$ TMAH solution. Pancreatin from porcine pancreas was obtained from Sigma Aldrich (Darmstadt, Germany). A solution with Triton $^{\circledR}$ (Merck, Darmstadt, Germany) and ammonium hydroxide $30 \%$ (Avantor Performance Materials, Netherlands) was used to wash up the ICP-MS sample introduction system.

\subsubsection{Selenium and iron determination}

Nitric acid (65\%) was distilled to ultrapure grade in an acid distillation system (Milestone SubPUR). Working standard, samples and blank solutions were prepared with a $2 \%(\mathrm{v} / \mathrm{v})$ nitric acid solution, while selenium and iron from single-element high purity ICP stock standard containing $1000 \mathrm{mg} / \mathrm{L}$ of selenium and $1000 \mathrm{mg} / \mathrm{L}$ of iron, respectively (SCP Science, Marktoberdorf, Germany). Internal standards of germanium, indium and yttrium solutions $(1000 \mathrm{mg} / \mathrm{L})$ were from Inorganic Ventures (Christiansburg, Virginia). The ICP-MS and the ICP-OES sample introduction system were washed up with a $2 \%(\mathrm{v} / \mathrm{v})$ nitric acid solution.

\subsection{Sample preparation}

\subsubsection{Iodine analysis}

The iodine content was determined with reference to EN 15111:2007 (European Committee for Standardization, 2007). A 48- well heating block (DigiPREP, SCP Science, Courtaboeuf, France) was used for sample extraction in alkaline media. 0.5-1 $\mathrm{g}$ samples that were weighed into $50 \mathrm{~mL}$ tubes and the extraction of iodine was performed by a graphite block system during $3 \mathrm{~h}$ at $90^{\circ} \mathrm{C}$ with TMAH solution. After extraction, all samples were centrifuged and filtered through $0.45 \mu \mathrm{m}$ filters. Some samples were pre-treated with a pancreatin solution overnight at $37^{\circ} \mathrm{C}$ before TMAH extraction to eliminate starch in its constitution.

\subsubsection{Selenium and iron analysis}

The selenium and iron content were determined according to EN 15763:2009 and AOAC 984.27, respectively (AOAC, 2002; European Committee for Standardization, 2009). Samples were digested in a closed-vessel microwave digestion system (Milestone ETHOS 1 Series). Samples were weighed and digested in Teflon vessels with a mixture of concentrated nitric acid, hydrogen peroxide and deionised water. Subsequently, the vessels were closed and introduced into a microwave oven. The program of microwave was established and optimised (Nascimento et al., 2014). After cooled to room temperature, digested samples were diluted with deionised water.

\subsection{Instrumentation}

Iodine and selenium were determined by an inductively coupled plasma mass spectrometer (ICP-MS), Thermo X series II, equipped with autosampler Cetac ASX-520, 1 mL.min ${ }^{-1}$ concentric glass nebuliser, air cooled quartz spray chamber, quartz $1.5 \mathrm{~mm}$ injector and nickel sample and skimmer cones. Operating conditions for ICP-MS were optimised as follows: Extraction: -220.0, Focus: 12.0 Pole Bias: -0.4, Hexapole Bias: -2.0, Nebuliser flow rate: $0.96 \mathrm{~L} \mathrm{~min}^{-1}$, Forward Power: $1400 \mathrm{~W}$, Cool gas flow rate: $13.9 \mathrm{~L} \mathrm{~min} \mathrm{~m}^{-1}$, Auxiliary gas flow rate: $0.95 \mathrm{~L} \mathrm{~min}{ }^{-1}$, Sampling Depth: 115, Standard Resolution: 132, High Resolution: 132, Analogue Detector: 1960, PC Detector: 3720. Measurements were performed using software Xseries PlasmaLab 2.5.

Iron was determined by an inductively coupled plasma optical emission spectrometer (ICP-OES), Thermo iCAP 6000 series, with radial and axial configuration. Instrumental settings of ICP-OES were specified in (Nascimento et al., 2014).

\subsection{Quality control}

The results reported in Table 1 were obtained in triplicate analytical samples under conditions of quality assurance supported by the requirements described in NP EN ISO/IEC 17025:2005 (European Committee for Standardization, 2005).

Precision and accuracy, limit of quantification (LoQ), selectivity, and an effective internal and external quality control program [Certified Reference Materials (CRM), spiked samples with chemical standards and participation in adequate Proficiency Testing (PT) Schemes] were carried out to ensure the analytical quality. Iodine, selenium and iron were quantified with a calibration curve for each and the correlation coefficient was $\geq 0.9995$. For each element, an internal quality control was used, and the acceptance criterion was $10 \%$. Matrix effects were monitored by adding an internal standard, and the results are discarded if the internal standard wasn't between $70 \%$ and $130 \%$, for iodine, and $80 \%$ and $120 \%$, for selenium and iron, respectively.

\subsection{Recommended nutrient intake}

The contribution for recommended nutrient intake (RNI) for iodine, selenium and iron for all age groups (WHO/FAO, 2004) were calculated taking into account the consumption data of each food group of the Portuguese population (Dofkova et al., 2016). The RNI of iron varies with a dietary bioavailability of this nutrient, thus, for calculations values corresponding to a dietary iron bioavailability of $15 \%$, were used, since the analysed samples are all protein-rich of animal origin 
Table 1

Results of quality control for iodine, selenium and iron determination.

\begin{tabular}{|c|c|c|c|c|}
\hline Matrix & $\begin{array}{l}\text { SRM/CRM/ } \\
\text { QCM }\end{array}$ & $\begin{array}{l}\text { Certified/ } \\
\text { Indicative value }\end{array}$ & $\begin{array}{l}\text { Observed } \\
\text { Value }\end{array}$ & Z-score \\
\hline \multicolumn{5}{|l|}{ Iodine $(\mu \mathrm{g} / \mathrm{kg})$} \\
\hline Infant Formula & $\begin{array}{l}\text { FAPAS } \\
07260\end{array}$ & 1065 & 1064 & 0.00 \\
\hline $\begin{array}{l}\text { Ready-made dish } \\
\text { with meat }\end{array}$ & $\begin{array}{l}\text { BIPEA 3- } \\
4432-0007\end{array}$ & 926 & 877 & -0.48 \\
\hline Fish & Spike & 1283 & 1272 & 0.04 \\
\hline Egg & Spike & 854 & 952 & -0.58 \\
\hline \multicolumn{5}{|l|}{ Selenium $(\mu \mathrm{g} / \mathrm{kg})$} \\
\hline Infant Formula & $\begin{array}{l}\text { FAPAS } \\
07260\end{array}$ & 158 & 139 & -0.60 \\
\hline $\begin{array}{l}\text { Ready-made dish } \\
\text { with meat }\end{array}$ & $\begin{array}{l}\text { BIPEA 3- } \\
4432-0007\end{array}$ & 1128 & 1034 & -1.22 \\
\hline Egg & Spike & 1430 & 1410 & 0.07 \\
\hline Fish & Spike & 1931 & 1818 & 0.29 \\
\hline \multicolumn{5}{|l|}{ Iron $(m g / l)$} \\
\hline Canned meat & Spike & 14.00 & 14.94 & -0.34 \\
\hline $\begin{array}{l}\text { Infant/adult } \\
\text { Formula }\end{array}$ & Nist 1849 & 17.71 & 17.45 & -0.20 \\
\hline
\end{tabular}

SRM - Standard Reference Material; CRM- Certified Reference Material; QCM Quality Control Material.

Table 2

Recommended nutrient intake for iodine, selenium and iron per age and sex group (World Health Organisation and Food and Agriculture Organization of the United Nations, 2004).

\begin{tabular}{llll}
\hline Age Group & Nutrient & Males & Females \\
\hline \multirow{2}{*}{$10-18$ years } & Iodine $(\mu \mathrm{g} /$ day) & 120 & 120 \\
& Selenium $(\mu \mathrm{g} /$ day) & 32 & 26 \\
& Iron $(\mathrm{mg} /$ day) & 11.1 & 21.3 \\
\multirow{2}{*}{$19-65$ years } & Iodine $(\mu \mathrm{g} /$ day) & 150 & 150 \\
& Selenium ( $\mu \mathrm{g} /$ day) & 34 & 26 \\
& Iron $(\mathrm{mg} /$ day) & 9.1 & 19.6 \\
\hline
\end{tabular}

(WHO/FAO, 2004). The RNI for iodine, selenium and iron were presented in Table 2.

\subsection{Statistical analysis}

All samples were analysed in triplicate and the results were expressed as mean and standard deviation (SD). Data was analysed by one-way analysis of variance (ANOVA) using the nonparametric Tukey-Kramer multiple comparison test to identify significances among seasons concerning the content of iodine, selenium and iron. Data with $\mathrm{P}<0.05$ were considered significant.

\section{Results and discussion}

\subsection{Quality assurance}

Proficiency test schemes (FAPAS and BIPEA) or a spiked sample with chemical standards were performed (Table 1) with Z-scores ranged from -1.22 to 0.29 .

\subsection{Nutrients contents of Portuguese food}

\subsubsection{Iodine content}

Iodine content varies a lot, from $<2.03 \mu \mathrm{g} / 100 \mathrm{~g}$ in group of meat to $163 \mu \mathrm{g} / 100 \mathrm{~g}$ in fish group (Table 3 ) with the left-censored data of $8 \%$ (4 out of 52).Its high content is in bivalves and molluscs with $157 \pm 6 \mu \mathrm{g} / 100 \mathrm{~g}$ and octopus are the lowest with $13.1 \pm 0.5 \mu \mathrm{g} /$ $100 \mathrm{~g}$. In subgroup of lean fish highest iodine content was for the
Atlantic cod, $138 \pm 1 \mu \mathrm{g} / 100 \mathrm{~g}$ and the lowest for the Atlantic salmon $(12.3 \pm 0.6 \mu \mathrm{g} / 100 \mathrm{~g})$. Concerning the fat fish, the highest content was for the mackerel, $40.6 \pm 1.1 \mu \mathrm{g} / 100 \mathrm{~g}$. Other authors indicate fish group with the highest iodine content, as a relevant contributor to the intake of this nutrient (Haldimann et al., 2005; Leufroy et al., 2015; Rose et al., 2001). The results of this work are in good agreement with previously published data (Haldimann et al., 2005; Leufroy et al., 2015; Rose et al., 2001), namely, with regard to seafood as the subgroup with the highest concentration of iodine. On the other hand, Nile perch presented lower values with $13.1 \pm 0.3 \mu \mathrm{g} / 100 \mathrm{~g}$, since it is a freshwater fish, thus with less iodine available than seawater fish (Haldimann et al., 2005).

In dairy products the amounts of iodine are not so high than in the fish group. Flavoured milks are the food with more concentration of iodine, $19.9 \pm 0.3 \mu \mathrm{g} / 100 \mathrm{~g}$, while Acidophilus yoghurt with $17.2 \pm 0.2 \mu \mathrm{g} / 100 \mathrm{~g}$ was the food with the lowest content in this group. Some authors have also reported identical values of dairy products from other European countries (studies without data of Portugal) (Cressey, 2003; van der Reijden et al., 2017).

The meat group had the lowest concentration of iodine among the groups studied without significant differences. The highest value within this group was found in the cold meat, a pool of various Portuguese dry sausages $(13.4 \pm 1.1 \mu \mathrm{g} / 100 \mathrm{~g})$, probably, from added additives, for example iodinated salt. Rabbit meat is the white meat with higher content, $7.83 \pm 0.39 \mu \mathrm{g} / 100 \mathrm{~g}$; this high value can be related to the metabolism of an animal of fast mobility, since the thyroid is associated with energy requirements (Schoenmakers et al., 1992). As regards to the red meat, the higher iodine content was found in sheep meat, $7.48 \pm 0.39 \mu \mathrm{g} / 100 \mathrm{~g}$. Values below the limit of quantification $(2.03 \mu \mathrm{g} / 100 \mathrm{~g})$ were found in all the other samples of this sub-group (bovine, calf and pork). In the literature, similar results were published, for example, meats from Switzerland the iodine content are in the range $3.40 \pm 1.40$ to $33.5 \pm 39.5 \mu \mathrm{g} / 100 \mathrm{~g}$, game and processed meat, respectively (Haldimann et al., 2005). Other authors have reported for meat from Norway, as a food group with the lowest iodine content (Dahl et al., 2004).

\subsubsection{Selenium content}

Selenium contents vary from $1.66 \mu \mathrm{g} / 100 \mathrm{~g}$ in dairy products to $138 \mu \mathrm{g} / 100 \mathrm{~g}$ in fish group (Table 3). In these food groups under this study all samples were quantified, so there is not left-censored data for selenium (Table 3).

Of all the foods analysed in this study, the highest concentration of selenium was for the European sardine with $132 \pm 5 \mu \mathrm{g} / 100 \mathrm{~g}$. The European conger was the lean fish that presented the highest content of this micronutrient, $81.6 \pm 1.5 \mu \mathrm{g} / 100 \mathrm{~g}$, and the shrimp with $69.4 \pm 3.9 \mu \mathrm{g} / 100 \mathrm{~g}$ was the seafood with higher content of selenium. Studies in France show that, as this study, the fish and seafood is the group with the highest content of selenium, with levels close to Portuguese fish sample analysed (Bourre and Paquotte, 2008; Leblanc et al., 2005; Noël et al., 2012). In an extended Brazilian study, where fruits were also included, higher concentration of selenium was for Brazil nut, followed by the fish group with close values of the Portuguese (dos Santos et al., 2017).

In the Portuguese foods of the meat group is the white meat that presented the highest content in selenium, more specifically chicken meat, $37.5 \pm 3.7 \mu \mathrm{g} / 100 \mathrm{~g}$. Pork is the red meat with a higher concentration of selenium, $21.7 \pm 0.7 \mu \mathrm{g} / 100 \mathrm{~g}$. Many authors only give importance to mammals in relation to the functions of selenium on terrestrial organisms (Lobanov et al., 2007). However, selenium may have unknown functions in the metabolism of poultry which may justify high selenium concentration in these animals (Sunde et al., 2015; Zhu et al., 2017). Other explanation for these values is the different feedstuffs contents. In the literature the selenium values for the meat group are very variable, from 25 to $106 \mu \mathrm{g} / 100 \mathrm{~g}$ (dos Santos et al., 2017; Hoffman-Pennesi et al., 2015), and between 4.2 and $33 \mu \mathrm{g} / 100 \mathrm{~g}$ 


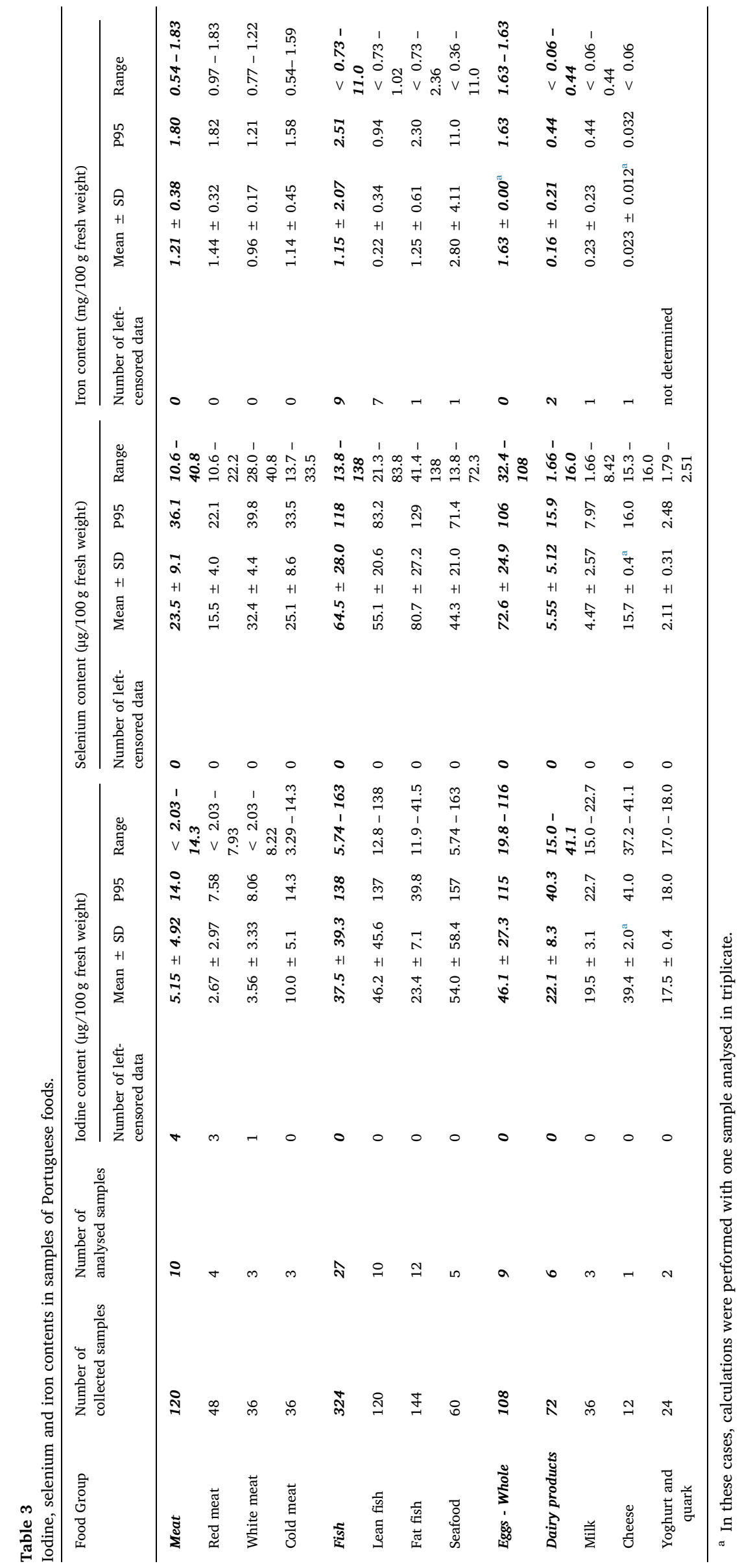


(Becker et al., 2011; Noël et al., 2012). One of the reasons for this variation is that the feeding of animals from different countries is diverse concerning selenium contents (dos Santos et al., 2017).

The food group with the lowest selenium content was dairy products, with highest level for cheeses in this group, $15.7 \pm 0.4 \mu \mathrm{g}$ / $100 \mathrm{~g}$. This is in agreement with the literature, although the selenium values for this group varies from a similar value up to more than 4 times (15 to $60 \mu \mathrm{g} / 100 \mathrm{~g}$ ) (Leblanc et al., 2005; Noël et al., 2012).

\subsubsection{Iron content}

Iron contents vary from less than $0.06 \mathrm{mg} / 100 \mathrm{~g}$ in group of dairy products to $11.0 \mathrm{mg} / 100 \mathrm{~g}$ in fish group (Table 3) with left-censored data of $21 \%$ (11 out of 52 ).

The highest content of iron was found in the group of seafood, bivalve molluscs (10.5 $\pm 0.9 \mathrm{mg} / 100 \mathrm{~g}$ ), but for shrimp contained much lower $(0.494 \pm 0.005 \mathrm{mg} / 100 \mathrm{~g})$ value. Regarding the fat fish, canned sardines had highest iron concentration, $2.32 \pm 0.07 \mathrm{mg} / 100 \mathrm{~g}$ and $0.967 \pm 0.057 \mathrm{mg} / 100 \mathrm{~g}$ horse mackerel, the lean fish with the highest content of this oligoelement. A study from China reported that shellfish was the aquatic food with highest iron content $(2.50 \mathrm{mg} / 100 \mathrm{~g}$ ) (Jiang et al., 2015). However, this value is substantially lower than is reported in current study. These differences can result from contents in oceans as well as the feeding supplementation with iron. Iron in the oceans can be affected by, for example, the dust of the deserts. Hence, comparing the Atlantic Ocean and the Pacific Ocean, the latter has less iron because it has a higher extension and the dust takes longer to be deposited (Mahowald et al., 2005).

The second group that contributes to higher iron intake is the meat group. Beef, from red meat, has a higher content, $1.81 \pm 0.02 \mathrm{mg}$ / $100 \mathrm{~g}$, since myoglobin is more abundant in this type of animals (Buzała et al., 2016; Moshe et al., 2013). The white meat with the highest concentration of iron is rabbit meat with $1.16 \pm 0.09 \mathrm{mg} / 100 \mathrm{~g}$ and the lower in chicken $(0.785 \pm 0.018 \mathrm{mg} / 100 \mathrm{~g})$. Frankfurter type sausages are the food belonging to the cold meat with the highest iron content, $1.57 \pm 0.02 \mathrm{mg} / 100 \mathrm{~g}$. Several works reported similar values for iron content in the meat group (Becker et al., 2011; Jiang et al., 2015; Millour et al., 2012).

Finally, the group of dairy products is the group with the lowest iron content. Within this group, most of the samples had iron content below the limit of quantification $(0.06 \mathrm{mg} / 100 \mathrm{~g})$. Two works found similar contents of iron for dairy products (Becker et al., 2011; Jiang et al., 2015).

It should note that iron has different biological forms. This affects its assimilation by organism (Mahowald et al., 2005; WHO/FAO, 2004).

\subsection{Seasonal variability in fish}

In Portugal two types of fish, sardines (Sardina plichardius) and mackerel (Scomber japonicus) are most consumed by the population and throughout the year. Therefore, it is also important to study their differences among seasons concerning the content of iodine, selenium and iron. These results are shown in Table 4. All samples for this study were bought in supermarket and were identified as caught on the Portuguese coast. Samples contained two or three fish of medium size $(10-15 \mathrm{~cm}$, sardines; $25-45 \mathrm{~cm}$, mackerel); each individual sample had $100 \mathrm{~g}$ of edible food.

\subsubsection{Iodine}

Regarding the iodine content in mackerel the highest value was observed in summer and the lowest in winter, without significant differences at 95\% confidence interval. Sardines had more significant differences among seasons than mackerel, mainly between summer and winter with $95 \%$ confidence interval. Higher value was in the autumn and the lowest in the spring. It is known that fish iodine levels vary not only among species but also between the same species (Fuge and Johnson, 2015; Rohner et al., 2014). This is most likely due to the
Table 4

Seasonal variability of the iodine, selenium and iron contents in fish.

\begin{tabular}{llll}
\hline & Iodine $(\mu \mathrm{g} / 100 \mathrm{~g})$ & Selenium $(\mu \mathrm{g} / 100 \mathrm{~g})$ & Iron $(\mathrm{mg} / 100 \mathrm{~g})$ \\
\hline Mackerel & Mean $\pm S D$ & Mean $\pm S D$ & Mean $\pm S D$ \\
Spring & $27.2 \pm 1.1$ & $98.8 \pm 2.7$ & $1.03 \pm 0.01$ \\
Summer & $40.6 \pm 1.1$ & $117 \pm 2$ & $1.13 \pm 0.04$ \\
Autumn & $30.8 \pm 1.1$ & $83.0 \pm 6.4$ & $1.15 \pm 0.03$ \\
Winter & $24.1 \pm 0.9$ & $62.0 \pm 1.1$ & n.d. \\
European Sardine & Mean $\pm S D$ & Mean $\pm S D$ & Mean $\pm S D$ \\
Spring & $17.4 \pm 0.4$ & $132 \pm 5$ & $1.48 \pm 0.02$ \\
Summer & $22.4 \pm 0.3$ & $61.0 \pm 5.6$ & $1.69 \pm 0.09$ \\
Autumn & $23.7 \pm 0.8$ & $64.2 \pm 3.5$ & $1.84 \pm 0.04$ \\
Winter & $22.0 \pm 1.0$ & $83.3 \pm 4.0$ & n.d. \\
\hline
\end{tabular}

feeding of each fish as well as its level of growth or metabolic requirements (Julshamn et al., 2006; Karl et al., 2001; Pehrsson et al., 2016), plausible explanations for the differences among seasons.

\subsubsection{Selenium}

The season with highest and the lowest content of selenium in mackerel, was the same for iodine, summer and winter, respectively, without significant differences at $95 \%$ confidence interval. Highest and lowest concentration of selenium for sardines were in spring and summer, respectively. Additionally, significant differences between summer and autumn were found. Similar results were previously published (Burger and Gochfeld, 2011; Saha et al., 2016). Summer or spring higher accumulation of selenium in fish may be from phytoplankton proliferation during this period. The decomposition of this biological species leads to an increase of selenium in the waters and consequent transfer to fish (Saha et al., 2016).

\subsubsection{Iron}

In relation to the iron content in mackerel autumn presented a higher concentration and the lower in spring, as well as significant differences between summer and autumn. In sardines, for iron content the seasons with higher and lower contents had the same pattern of iodine, without significant differences among seasons with a $95 \%$ confidence interval, as was published before (Dural et al., 2007; Ongeri et al., 2012), although with higher content in the summer (Mendil et al., 2010). Leaching of soils in rainy seasons and consequent dragging of ions to the oceans could be the cause (Dural et al., 2007).

\subsection{Food composition databases}

In order to demonstrate the importance of updates in the food composition tables for each country, Table 5 compares the iodine, selenium and iron contents of this study with several food composition tables (ANSES, 2018; Food Standards Australia New Zealand, 2018; FRI, 2016; IFR, 2018; National Institute for Health and Welfare, 2018; RIVM, 2018). The Portuguese Food Database has data only for iron content, but not for iodine and selenium. So, this study can lead to an update the Portuguese FCDB concerning new oligoelements, as well as to improve health standards based on new information now available.

\subsubsection{Iodine}

Iodine content in foods of different food composition databases (FCDBs) have higher values in the fish and seafood, as expected, based on Finnish and Australian databases, although with highest values. Both countries have implemented a salt iodization program as well as fortification of cows feeding (Ershow et al., 2018; Nyström et al., 2016) is a plausible explanation. The fish group have the biggest differences among databases, although in the meat group we highlight Finland case with a much higher value, probably as consequence of iodine spreading to hydrosphere after salt iodisation program and fortification cows feeding. Regarding eggs, the variation is not so great and in milk the 
Table 5

Comparison between food composition databases for iodine, selenium and iron.

\begin{tabular}{|c|c|c|c|c|c|c|}
\hline $\begin{array}{l}\text { Food composition } \\
\text { databases }\end{array}$ & $\begin{array}{l}\text { Salmon (steamed or oven- } \\
\text { baked or grilled) }\end{array}$ & $\begin{array}{l}\text { Shrimp (fried or } \\
\text { boiled) }\end{array}$ & $\begin{array}{l}\text { Beef, steak or beef steak } \\
\text { (grilled or roasted or fried) }\end{array}$ & $\begin{array}{l}\text { Chicken, meat and skin (roasted } \\
\text { or baked or grilled) }\end{array}$ & $\begin{array}{l}\text { Milk, whole } \\
\text { (UHT) }\end{array}$ & Egg (boiled) \\
\hline \multicolumn{7}{|l|}{ Iodine $(\mu \mathrm{g} / 100 \mathrm{~g})$} \\
\hline This study & $12^{\mathrm{a}}$ & $71^{\mathrm{a}}$ & $<2.01^{\mathrm{a}}$ & $2^{\mathrm{a}}$ & $16^{\mathrm{a}}$ & $24^{\mathrm{a}}$ \\
\hline Finland & $104.7^{\mathrm{c}}$ & $210^{\mathrm{a}}$ & $33.7^{c}$ & $34.1^{\mathrm{c}}$ & $16.4^{\mathrm{a}}$ & $42.3^{c}$ \\
\hline France & $17^{\mathrm{d}}$ & $22^{\mathrm{d}}$ & $6^{\mathrm{d}}$ & $5^{\mathrm{d}}$ & $<20^{\mathrm{a}}$ & $50.4^{\mathrm{a}}$ \\
\hline Netherlands & $8^{c}$ & $55^{\mathrm{a}}$ & $9^{\mathrm{a}}$ & $7^{\mathrm{a}}$ & $14.9^{\mathrm{a}}$ & $31.3^{\mathrm{a}}$ \\
\hline United Kingdom & $14^{\mathrm{a}}$ & $100^{\mathrm{d}}$ & $11^{\mathrm{a}}$ & $6^{\mathrm{a}}$ & $31^{\mathrm{a}}$ & $52^{\mathrm{a}}$ \\
\hline Australia & $9.6^{\mathrm{b}}$ & $310^{\mathrm{a}}$ & $0.5^{\mathrm{b}}$ & $0.7^{\mathrm{b}}$ & $22.3^{\mathrm{a}}$ & $70^{\mathrm{b}}$ \\
\hline Slovakia & $34^{\mathrm{d}}$ & $100^{\mathrm{d}}$ & n. p. & n. p. & $28^{\mathrm{d}}$ & $8.8^{\mathrm{d}}$ \\
\hline \multicolumn{7}{|c|}{ Selenium $(\mu \mathrm{g} / 100 \mathrm{~g})$} \\
\hline This study & $43^{\mathrm{a}}$ & $69^{\mathrm{a}}$ & $14^{\mathrm{a}}$ & $38^{\mathrm{a}}$ & $4^{a}$ & $34^{\mathrm{a}}$ \\
\hline Finland & $30.2^{\mathrm{c}}$ & $21^{\mathrm{a}}$ & $21.3^{\mathrm{c}}$ & $30.6^{c}$ & $2.9^{c}$ & $33^{c}$ \\
\hline France & $19^{\mathrm{a}}$ & $41.7^{\mathrm{d}}$ & $<10^{\mathrm{a}}$ & $5.66^{\mathrm{a}}$ & $<50^{\mathrm{a}}$ & $23.8^{\mathrm{a}}$ \\
\hline Netherlands & $22^{\mathrm{c}}$ & $31^{\mathrm{a}}$ & $9^{a}$ & n. p. & $2^{\mathrm{a}}$ & $17^{\mathrm{a}}$ \\
\hline United Kingdom & $32^{\mathrm{a}}$ & $46^{\mathrm{d}}$ & $10^{\mathrm{a}}$ & $15^{\mathrm{a}}$ & $1^{\mathrm{a}}$ & $27^{\mathrm{a}}$ \\
\hline Australia & $29.4^{\mathrm{b}}$ & $8^{\mathrm{a}}$ & $5^{\mathrm{b}}$ & $26.3^{\mathrm{b}}$ & $1.2^{\mathrm{a}}$ & $30^{\mathrm{b}}$ \\
\hline Slovakia & $31^{\mathrm{d}}$ & $46^{\mathrm{d}}$ & n. p. & n. p. & $5^{\mathrm{d}}$ & $8^{\mathrm{d}}$ \\
\hline \multicolumn{7}{|l|}{ Iron $(\mathrm{mg} / 100 \mathrm{~g})$} \\
\hline This study & $<0.7^{\mathrm{a}}$ & $0.49^{\mathrm{a}}$ & $2^{\mathrm{a}}$ & $0.8^{\mathrm{a}}$ & $<0.06^{\mathrm{a}}$ & $2^{\mathrm{a}}$ \\
\hline Finland & $0.5^{\mathrm{c}}$ & $3.6^{\mathrm{d}}$ & $4.2^{\mathrm{c}}$ & $0.9^{\mathrm{c}}$ & $<0.1^{\mathrm{d}}$ & $1.7^{\mathrm{c}}$ \\
\hline France & $0.4^{\mathrm{d}}$ & $1^{\mathrm{d}}$ & $2,21^{\mathrm{a}}$ & $0.68^{\mathrm{d}}$ & $0.01^{\mathrm{a}}$ & $1.9^{\mathrm{a}}$ \\
\hline Netherlands & $0.3^{c}$ & $0,2^{\mathrm{a}}$ & $2^{\mathrm{a}}$ & $1.3^{\mathrm{a}}$ & $0^{\mathrm{a}}$ & $2.3^{\mathrm{a}}$ \\
\hline United Kingdom & $0.60^{\mathrm{a}}$ & $1.80^{\mathrm{d}}$ & $2.30^{\mathrm{a}}$ & $0.60^{\mathrm{a}}$ & $0.23^{\mathrm{a}}$ & $1.97^{\mathrm{a}}$ \\
\hline Australia & $1.4^{\mathrm{b}}$ & $6.8^{\mathrm{a}}$ & $0.96^{\mathrm{b}}$ & $0.58^{\mathrm{b}}$ & $0.03^{\mathrm{a}}$ & $1.82^{\mathrm{b}}$ \\
\hline Slovakia & $0.83^{\mathrm{d}}$ & $1.8^{\mathrm{d}}$ & $3.32^{\mathrm{d}}$ & $1.21^{\mathrm{d}}$ & n. p. & $0.5^{\mathrm{d}}$ \\
\hline
\end{tabular}

n. p. - not presented.

a Original analytical values.

b Imputed values.

c Calculated values.

d Borrowed values.

variation is practically insignificant. The iodine values found in this study are always among the three lowest values. This leads us once again to conclude that Portugal should implement programs to increase the iodine intake in the diet, taking into account the metabolic importance of this nutrient for humans.

\subsubsection{Selenium}

The differences in the food composition databases for selenium contents are not as high for iodine. The results obtained in this article are higher than those from databases except for beef and milk. However, for these two cases this study shows the second highest value of selenium. Comparing databases it is verified that the same food has not the highest selenium levels in all countries. For example, in Finland and Australia the highest food content is for eggs, while in all other countries it is either salmon or shrimp. In the literature some geographical factors are pointed out as being responsible for the selenium variation in soils (dos Santos et al., 2017; Foster and Sumar, 1997; Hoffman-Pennesi et al., 2015). These variations may cause impoverishment of selenium in food.

\subsubsection{Iron}

In the case of iron contents there are no differences in the food composition databases analysed. However, in all the databases there is no food with a higher content. There are differences concerning iron content, for example, in case of beef iron concentration varies from $0.96 \mathrm{mg} / 100 \mathrm{~g}$ in Australia to $4.2 \mathrm{mg} / 100 \mathrm{~g}$ in Finland (Food Standards Australia New Zealand, 2018; National Institute for Health and Welfare, 2018). It is also possible to identify that herein the fish group and milk belong to the group with the lowest levels, while in the remaining foods the values are close of the average for all databases.

\subsection{Recommended nutrient intake}

The $\%$ RNI for iodine, selenium and iron of one or two foods were chosen from each of the four groups studied, corresponding to a total of six selected foods (salmon, shrimp, bovine, chicken, milk and egg), are shown in Fig. 1. The food that contributes most to the RNI of iodine and selenium is the shrimp, while for iodine $32.3 \%$ for female children and $38.4 \%$ for adult males. In the case of selenium, $\%$ RNI is much higher, ranging from $131 \%$ for children (males) to $178 \%$ for women adult. In the case of iron all foods studied have a contribution to RNI lower than $10 \%$, with a exception of bovine in a range from $6.06 \%$ (children female) to $21.1 \%$ (men). Egg has the lowest RNI for iron and selenium, with $7.71 \%$ for selenium and $1.57 \%$ for iron. The $\%$ RNI for iodine was egg below than $1.14 \%$. It was reported that fish was the food group with the highest content of iodine and selenium (Leblanc et al., 2005; Leufroy et al., 2015; Noël et al., 2012). Other useful source of iodine was dairy products and eggs. However, eggs contribute less to the intake of selenium (Leblanc et al., 2005; Leufroy et al., 2015; Noël et al., 2012). In the case of iron fish was a bigger contributor to iron intake (Jiang et al., 2015), however other authors report that sweetened foods contain a higher concentration of this micronutrient (Millour et al., 2012).

All of these contributions could be lower taking into account the bioavailability of each nutrient typically is not $100 \%$. For example, iron just a low percentage is assimilated by organism (WHO/FAO, 2004) depending of its biological form.

\section{Conclusions}

The present study was designed to provide combined information on contents of iodine, selenium and iron in representative key foods of Portuguese diet. Fish and milk are the major sources of iodine. The selenium intake in shrimp is well over the \% RNI. Although bovine have the highest iron content, however, their contribution to the iron RNI is low. Further studies are necessary to characterise iodine, selenium and iron intake by target groups, for example pregnant woman to define the adequate intake and prevent thyroid diseases. 

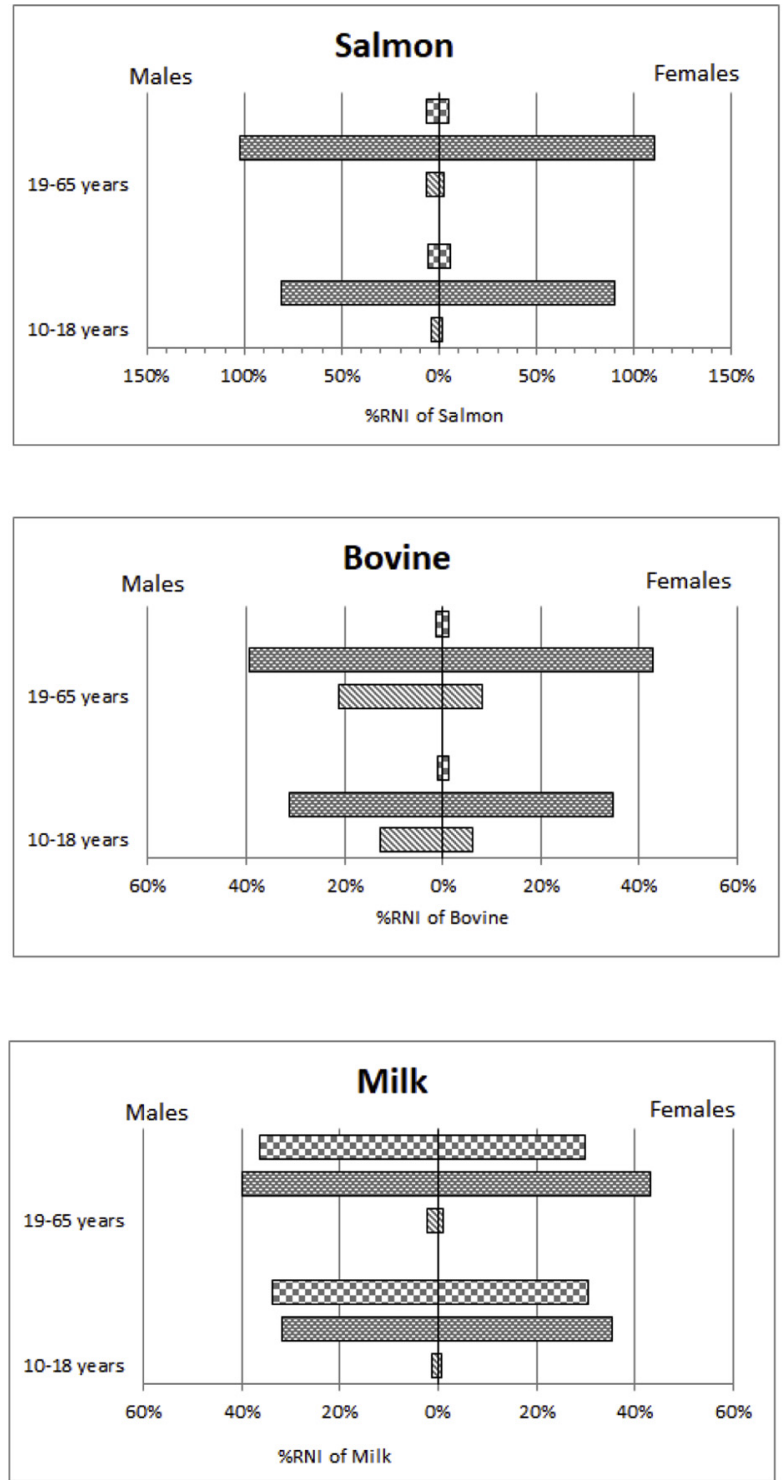
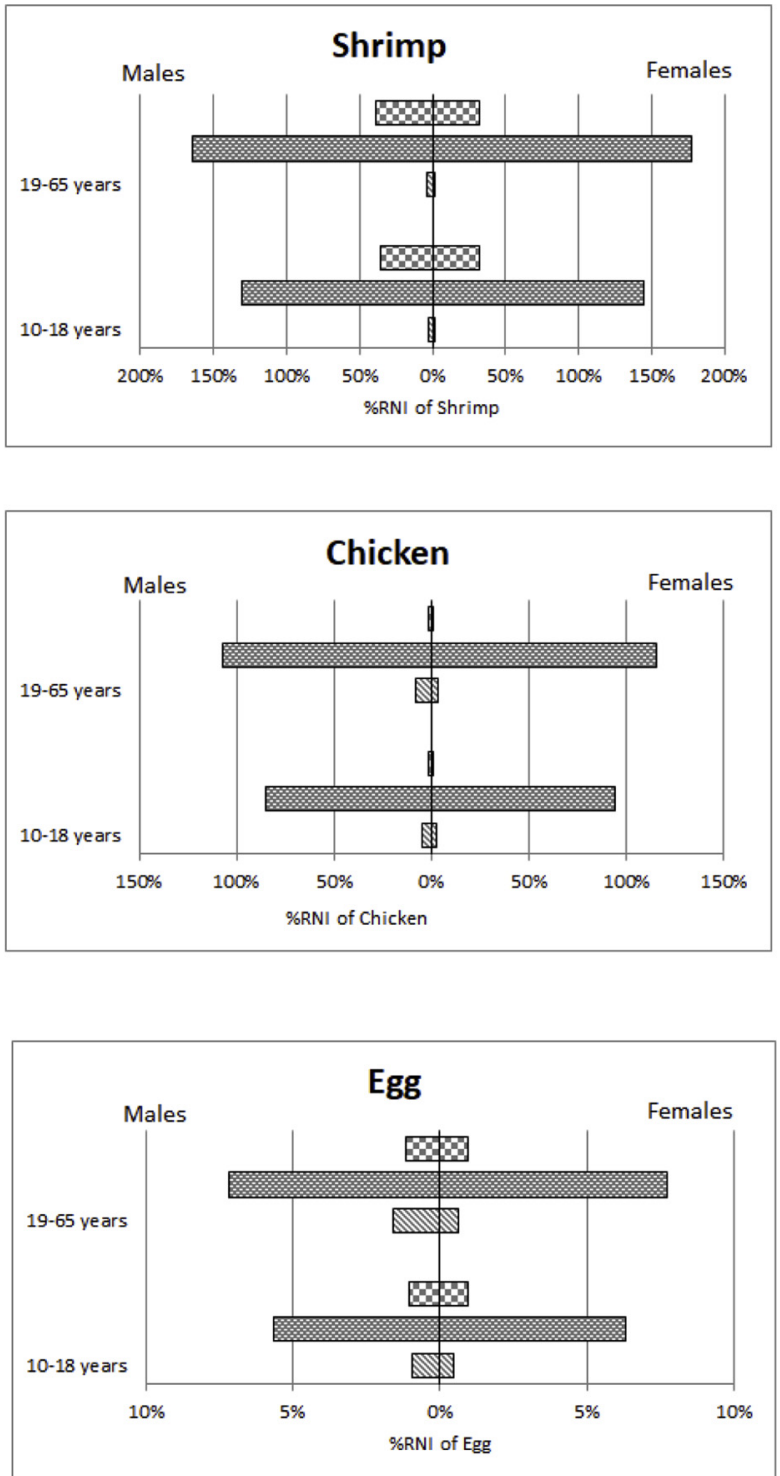

Fig. 1. Contribution for iodine, selenium and iron RNI (\%) for different ages and males and females. $\mathbb{B}$ - Iodine; $\mathbf{5}$ - Selenium; $\mathbb{\mathbb { N }}$ - Iron.

Additionally, other sources of food, as vegetables and fruits, can supply significantly some of these oligoelements.

\section{Acknowledgments}

The scientific work was funded by the Project WHO Collaborating Centre funded by the Instituto Nacional de Saúde Doutor Ricardo Jorge, I.P. Lisbon, Portugal (2013DAN850) and by the PRO-METROFOOD project, funded by European Union's Horizon 2020 research and innovation programme under grant agreement No 739568.

\section{Appendix A. Supplementary data}

Supplementary material related to this article can be found, in the online version, at doi:https://doi.org/10.1016/j.jfca.2019.03.004.

\section{References}

ANSES, 2018. CIQUAL French Food Composition Table. [WWW Document]. URL. (Accessed 19 March 2018). https://ciqual.anses.fr/.

AOAC, 2002. Association of Official Analytical Chemists 984.27 (50.1.15) - Method to determine Calcium, Copper, Iron, Magnesium, Manganese, Phosphorous, Potasium, Sodium and Zinc in Infant Formula.
Arthur, J.R., Beckett, G.J., Mitchell, J.H., 1999. The interactions between selenium and iodine deficiencies in man and animals. Nutr. Res. Rev. 12, 55-73. https://doi.org/ 10.1079/095442299108728910.

Becker, W., Jorhem, L., Sundström, B., Grawé, K.P., 2011. Contents of mineral elements in Swedish market basket diets. J. Food Anal. 24, 279-287. https://doi.org/10.1016/j. jfca.2010.10.001.

Bourre, J.M., Paquotte, P., 2008. Seafood (wild and farmed) for the elderly: contribution to the dietary intakes of iodine, selenium, DHA and vitamins B12 and D. J. Nutr. Heal. Aging 12, 186-192. https://doi.org/10.1007/BF02982617.

Boyages, S.C., 1993. Clinical review 49: iodine deficiency disorders. J. Clin. Endocrinol. Metab. 77, 587-591. https://doi.org/10.1210/jcem.77.3.8370679.

Burger, J., Gochfeld, M., 2011. Mercury and selenium levels in 19 species of saltwater fish from New Jersey as a function of species, size, and season. Sci. Total Environ. 409, 1418-1429. https://doi.org/10.1016/j.scitotenv.2010.12.034.

Buzała, M., Słomka, A., Janicki, B., 2016. Heme iron in meat as the main source of iron in the human diet. J. Elemntol. 21, 303-314. https://doi.org/10.5601/jelem.2015.20.1. 850 .

Cressey, P., 2003. Iodine content of New Zealand dairy products. J. Food Anal. 16, 25-36. https://doi.org/10.1016/S0889-1575(02)00132-1.

Dahl, L., Johansson, L., Julshamn, K., Meltzer, H.M., 2004. The iodine content of Norwegian foods and diets. Public Health Nutr. 7, 569-576. https://doi.org/10. 1079/PHN2003554.

Dofkova, M., Nurmi, T., Berg, K., Reykadal, Ó., Gunnlaugsdóttir, H., Vasco, E., Dias, M.G., Blahova, J., Rehurkova, I., Putkonen, T., Ritvanen, T., Lindtner, O., Desnica, N., Jörundsdóttir, H.O., Oliveira, L., Ruprich, J., 2016. Development of harmonised food and sample lists for total diet studies in five European countries. Food Addit. Contam. Part A 33, 933-944. https://doi.org/10.1080/19440049.2016.1189770.

dos Santos, M., da Silva Júnior, F.M.R., Muccillo-Baisch, A.L., 2017. Selenium content of Brazilian foods: a review of the literature values. J. Food Anal. 58, 10-15. https://doi. 
org/10.1016/j.jfca.2017.01.001

Dural, M., Göksu, M.Z.L., Özak, A.A., 2007. Investigation of heavy metal levels in economically important fish species captured from the Tuzla lagoon. Food Chem. 102, 415-421. https://doi.org/10.1016/j.foodchem.2006.03.001.

Egan, M.B., Fragodt, A., Raats, M.M., Hodgkins, C., Lumbers, M., 2007. The importance of harmonizing food composition data across Europe. Eur. J. Clin. Nutr. 61, 813-821. https://doi.org/10.1038/sj.ejcn.1602823.

Elegbede, C.F., Papadopoulos, A., Kolbaum, A.E., Turrini, A., Mistura, L., Lindtner, O., Eronique Sirot, V., Fabrice Elegbede, C., Papadopoulos, A., Kolbaum, A.E., Turrini, A., Mistura, L., Lindtner, O., Sirot, V., 2017. TDS exposure project: how and when to consider seasonalityin a total diet study? Food Chem. Toxicol. 105, 119-126. https:// doi.org/10.1016/j.fct.2017.03.045.

Ershow, A.G., Skeaff, S.A., Merkel, J.M., Pehrsson, P.R., 2018. Development of databases on iodine in foods and dietary supplements. Nutrients 10, 1-20. https://doi.org/10. 3390/nu10010100.

European Committee for Standardization, 2005. ISO/IEC 17025:2005 - General Requirements for the Competence of Testing and Calibration Laboraroties.

European Committee for Standardization, 2007. EN 15111 - Foodstuffs - Determination of Trace Elements - Determination of Iodine by ICP-MS (Inductively Coupled Plasma Mass Spectrometry).

European Committee for Standardization, 2009. EN 15763:2009 - Foodstuffs Determination of Trace Elements - Determination of Arsenic, Cadmium, Mercury and Lead in Foodstuffs by Inductively Coupled Plasma Mass Spectrometry (ICP- MS) After Pressure Digestion.

European Food Safety Authority (EFSA), 2015. The Food Classification and Description System FoodEx 2 (revision 2). EFSA Support. Publ. 2015EN-804 99. https://doi.org/ 10.2903/sp.efsa.2015.EN-804.

Food Standards Australia New Zealand, 2018. Food Nutrient Database - Australia. [WWW Document]. URL. (Accessed 19 March 2018). http://www.foodstandards. gov.au/science/monitoringnutrients/ausnut/foodnutrient/Pages/default.aspx.

Foster, L.H., Sumar, S., 1997. Selenium in health and disease: a review. Crit. Rev. Food Sci. Nutr. 37, 211-228. https://doi.org/10.1080/10408399709527773.

FRI, 2016. Slovak Food Composition Data Bank. [WWW Document]. URL. (Accessed 19 March 2018). http://www.pbd-online.sk/en.

Fuge, R., Johnson, C.C., 2015. Iodine and human health, the role of environmental geochemistry and diet, a review. Appl. Geochem. 63, 282-302. https://doi.org/10. 1016/j.apgeochem.2015.09.013.

Greenfield, H., Southgate, Da.T., 1992. Food Composition Data. Springer US, Boston, MA. https://doi.org/10.1007/978-1-4615-3544-7.

Haldimann, M., Alt, A., Blanc, A., Blondeau, K., 2005. Iodine content of food groups. J. Food Anal. 18, 461-471. https://doi.org/10.1016/j.jfca.2004.06.003.

Hess, S.Y., Zimmermann, M.B., Arnold, M., Langhans, W., Hurrell, R.F., 2002. Iron deficiency anemia reduces thyroid peroxidase activity in rats. J. Nutr. 132, 1951-1955. https://doi.org/10.1093/jn/132.7.1951.

Hoffman-Pennesi, D., Spungen, J., Rabbani, P.I., Briguglio, S., Wirtz, M., 2015. Evaluation of U.S. Total diet study data on selenium. Procedia Food Sci. 4, 79-85. https://doi. org/10.1016/j.profoo.2015.06.012.

Hu, S., Rayman, M.P., 2017. Multiple nutritional factors and the risk of hashimoto's Thyroiditis. Thyroid 27, 597-610. https://doi.org/10.1089/thy.2016.0635.

IFR, 2018. McCance and Widdowson's the Composition of Foods Integrated Dataset. [WWW Document]. URL. (Accessed 19 March 2018). https://www.gov.uk/ government/publications/composition-of-foods-integrated-dataset-cofid.

Jiang, J., Lu, S., Zhang, H., Liu, G., Lin, K., Huang, W., Luo, R., Zhang, X., Tang, C., Yu, Y., 2015. Dietary intake of human essential elements from a Total Diet Study in Shenzhen, Guangdong Province, China. J. Food Compos. Anal. 39, 1-7. https://doi. org/10.1016/j.jfca.2014.10.012.

Julshamn, K., Maage, A., Waagbø, R., Lundebye, a.K., 2006. A preliminary study on tailoring of fillet iodine concentrations in adult Atlantic salmon (Salmo salar L.) through dietary supplementation. Aquac. Nutr. 12, 45-51. https://doi.org/10.1111/ j.1365-2095.2006.00380.x.

Karl, H., Münkner, W., Krause, S., Bagge, I., 2001. Determination, spatial variation and distribution of iodine infish. Dtsch. Leb. Rundsch. 97 (3), 89-96.

Köhrle, J., 2013. Selenium and the thyroid. Curr. Opin. Endocrinol. Diabetes Obes. 20 , 441-448. https://doi.org/10.1097/01.med.0000433066.24541.88.

Leblanc, J.-C., Guérin, T., Noël, L., Calamassi-Tran, G., Volatier, J.-L., Verger, P., 2005. Dietary exposure estimates of 18 elements from the 1st French Total Diet Study. Food Addit. Contam. 22, 624-641. https://doi.org/10.1080/02652030500135367.

Leufroy, A., Noël, L., Bouisset, P., Maillard, S., Bernagout, S., Xhaard, C., de Vathaire, F., Guérin, T., 2015. Determination of total iodine in French Polynesian foods: method validation and occurrence data. Food Chem. 169, 134-140. https://doi.org/10.1016/ j.foodchem.2014.07.142.

Lobanov, A.V., Fomenko, D.E., Zhang, Y., Sengupta, A., Hatfield, D.L., Gladyshev, V.N., 2007. Evolutionary dynamics of eukaryotic selenoproteomes: large selenoproteomes may associate with aquatic life and small with terrestrial life. Genome Biol. 8, R198. https://doi.org/10.1186/gb-2007-8-9-r198.

Mahowald, N.M., Baker, A.R., Bergametti, G., Brooks, N., Duce, R.A., Jickells, T.D.,
Kubilay, N., Prospero, J.M., Tegen, I., 2005. Atmospheric global dust cycle and iron inputs to the ocean. Global Biogeochem. Cycles 19https://doi.org/10.1029/ 2004GB002402. n/a-n/a.

Mendil, D., Demirci, Z., Tuzen, M., Soylak, M., 2010. Seasonal investigation of trace element contents in commercially valuable fish species from the Black sea. Turkey. Food Chem. Toxicol. 48, 865-870. https://doi.org/10.1016/j.fct.2009.12.023.

Millour, S., Noël, L., Chekri, R., Vastel, C., Kadar, A., Sirot, V., Leblanc, J.-C., Guérin, T., 2012. Strontium, silver, tin, iron, tellurium, gallium, germanium, barium and vanadium levels in foodstuffs from the Second French Total Diet Study. J. Food Anal. 25, 108-129. https://doi.org/10.1016/j.jfca.2011.10.004.

Moshe, G., Amitai, Y., Korchia, G., Korchia, L., Tenenbaum, A., Rosenblum, J., Schechter, A., 2013. Anemia and Iron deficiency in children. J. Pediatr. Gastroenterol. Nutr. 57, 722-727. https://doi.org/10.1097/MPG.0b013e3182a80c42.

Nascimento, A.C., Mota, C., Coelho, I., Guefão, S., Santos, M., Matos, A.S., Castanheira, I., 2014. Characterisation of nutrient profile of quinoa (Chenopodium quinoa), amaranth (Amaranthus caudatus), and purple corn (Zea mays L.) consumed in the North of Argentina: Proximates, minerals and trace elements. Food Chem. 148, 420-426. https://doi.org/10.1016/j.foodchem.2013.09.155.

National Institute for Health and Welfare, 2018. Fineli - Food Composition Database Finland. [WWW Document]. URL. (Accessed 19 March 2018). https://fineli.fi/ fineli/en/index?

Noël, L., Chekri, R., Millour, S., Vastel, C., Kadar, A., Sirot, V., Leblanc, J.-C., Guérin, T. 2012. Li, Cr, Mn, Co, Ni, Cu, Zn, Se and Mo levels in foodstuffs from the Second French TDS. Food Chem. 132, 1502-1513. https://doi.org/10.1016/j.foodchem. 2011.12.009.

Nyström, H.F., Brantsæter, A.L., Erlund, I., Gunnarsdottir, I., Hulthén, L., Laurberg, P., Mattisson, I., Rasmussen, L.B., Virtanen, S., Meltzer, H.M., 2016. Iodine status in the Nordic countries - past and present. Food Nutr. Res. 60, 31969. https://doi.org/10. 3402/fnr.v60.31969.

Ongeri, D.M.K., Lalah, J.O., Wandiga, S.O., Schramm, K.-W., Michalke, B., 2012. Seasonal variability in cadmium, lead, copper, zinc and iron concentrations in the three major fish species, Oreochromis niloticus, Lates niloticus and Rastrineobola argentea in Winam Gulf, Lake Victoria: impact of wash-off into the lake. Bull. Environ. Contam. Toxicol. 88, 166-171. https://doi.org/10.1007/s00128-011-0472-z.

Ottley, C., 2005. Food composition databases. Trends Food Sci. Technol. 16, 507-509. https://doi.org/10.1016/j.tifs.2005.08.003.

Pehrsson, P.R., Patterson, K.Y., Spungen, J.H., Wirtz, M.S., Andrews, K.W., Dwyer, J.T., Swanson, C.A., 2016. Iodine in food- and dietary supplement - composition databases 1-3. J. Nutr. 104, 868-876. https://doi.org/10.3945/ajcn.115.110064.1.

RIVM, 2018. NEVO - Food Composition Database - Netherlands. [WWW Document]. URL. (Accessed 19 March 2018). https://nevo-online.rivm.nl/.

Rohner, F., Zimmermann, M., Jooste, P., Pandav, C., Caldwell, K., Raghavan, R., Raiten, D.J., 2014. Biomarkers of nutrition for development - iodine review. J. Nutr. 144, 1322S-1342S. https://doi.org/10.3945/jn.113.181974.

Rose, M., Miller, P., Baxter, M., Appleton, G., Crews, H., Croasdale, M., 2001. Bromine and iodine in 1997 UK total diet study samples. J. Environ. Monit. 3, 361-365. https://doi.org/10.1039/b105695f.

Saha, N., Mollah, M.Z.I., Alam, M.F., Safiur Rahman, M., 2016. Seasonal investigation of heavy metals in marine fishes captured from the Bay of Bengal and the implications for human health risk assessment. Food Control 70, 110-118. https://doi.org/10. 1016/j.foodcont.2016.05.040.

Schoenmakers, C.H.H., Pigmans, I.G.A.J., Visser, T.J., 1992. Species differences in liver type I iodothyronine deiodinase. Biochim. Biophys. Acta Protein Struct. Mol. Enzymol. 1121, 160-166. https://doi.org/10.1016/0167-4838(92)90349-I.

Sunde, R.A., Sunde, G.R., Sunde, C.M., Sunde, M.L., Evenson, J.K., 2015. Cloning, sequencing, and expression of selenoprotein transcripts in the Turkey (Meleagris gallopavo). PLoS One 10, e0129801. https://doi.org/10.1371/journal.pone.0129801.

van der Reijden, O.L., Zimmermann, M.B., Galetti, V., 2017. Iodine in dairy milk: sources, concentrations and importance to human health. Best Pract. Res. Clin. Endocrinol. Metab. 31, 385-395. https://doi.org/10.1016/j.beem.2017.10.004.

WHO/FAO, 2004. Vitamin and Mineral Requirements in Human Nutrition.

Yao, Y., Pei, F., Kang, P., 2011. Selenium, iodine, and the relation with Kashin-Beck disease. Nutrition 27, 1095-1100. https://doi.org/10.1016/j.nut.2011.03.002.

Zhu, S.-Y., Li, X.-N., Sun, X.-C., Lin, J., Li, W., Zhang, C., Li, J.-L., 2017. Biochemical characterization of the selenoproteome in Gallus gallus via bioinformatics analysis: structure-function relationships and interactions of binding molecules. Metallomics 9, 124-131. https://doi.org/10.1039/C6MT00254D.

Zimmermann, M.B., 2012. iodine and iodine deficiency disorders. Present Knowledge in Nutrition. Wiley-Blackwell, Oxford, UK, pp. 554-567. https://doi.org/10.1002/ 9781119946045.ch36.

Zimmermann, M.B., Köhrle, J., 2002. The impact of iron and selenium deficiencies on iodine and thyroid metabolism: biochemistry and relevance to public health. Thyroid 12, 867-878. https://doi.org/10.1089/105072502761016494.

Zimmermann, M., Adou, P., Torresani, T., Zeder, C., Hurrell, R., 2000. Persistence of goiter despite oral iodine supplementation in goitrous children with iron deficiency anemia in Cote d'Ivoire. Am. J. Clin. Nutr. 71, 88-93. 